\title{
Dependent and Functional Relationship of Finance and Economics on Sustainable Development specially in Indian Economy
}

\author{
${ }^{1}$ Matloob Ullah Khan., ${ }^{2}$ Dr. Sadaf Siraj \\ ${ }^{I}$ (Research Scholar, Department of Management, Jamia Hamdard, New Delhi, India) \\ ${ }^{2}$ (Assistant Professor, Department of Management, Jamia Hamdard, New Delhi, India)
}

\begin{abstract}
The main objective of this paper is to understand the concept of Sustainable Development and study the relationship between Finance, Economics and Sustainable Development. This paper attempts to create a functional and mathematical structure to show sustainable development and its relationship with Finance and Economics, and show how these three of them are strongly related to each along with the method of error calculation between these variable.
\end{abstract}

Keywords: Dependent and Functional Relationship, Economics, Finance and Sustainable Development.

\section{Introduction}

Sustainable development (SD) is an arrangement of reserve use that aims to come across human needs while protective the environment so that these needs can be met not only in the present-days but also for generations to come. The term was used by the Brundtland Commission which make something your own and what has become the most often-quoted definition of sustainable development as development that "meets the needs of the present without negotiating the ability of future generations to meet their own needs"[1][2]. Sustainable development bonds together concern for the carrying capacity of systems through the social challenges facing humanity. As early as the 1970's "Sustainability" was active to describe an economy "in equilibrium with basic ecological support systems"[3]. Ecologists have pointed to the Limits to growth, and presented the alternative of a "Steady State Economy"[4] in order to address environmental concerns.

Sustainable development does not emphasis completely on environmental problems. The United Nations 2005 World Summit outcome document refers to the "Codependent and mutually strengthening pillars" of sustainable development as economic development, social development, and environmental protection. Home-grown peoples have debated, through various international forums such as the United Nations Permanent Forum on Aboriginal Issues and the agreement on Biological Diversity, that there are four pillars of sustainable development, the fourth being cultural. In today's mutually dependent world, trade and industry trends that start in one country affect many others, and national economies are affected by the internationalization of production and international trade. Resource management, pollution control and climate sensations are all issues that by their nature reach beyond geographic borders, making the challenges of sustainability significance shared by countries and societies universally.

\section{Literature Review}

When we talk about relationship between finance, economics and sustainable development, we found limited resources of research which are conducted in this sector. Most of the research are take place in developed countries where possibility of error is very least which shown in mathematical derivation segment of this paper but when we developed this relationship on the basis of developing countries just like India, so we are not getting possible outcome due to high level of error problem which occur due to high level of miss management of funds. Some relevant literatures are given blow which shows the relationship between these variables.

To representing the relationship between finance and economic development [5] Levine (1997), found that countries with established banking sector and energetic stock market grew faster economic level over the period compared with the countries had wrapped financial system. [6] Beck (2000), found in his study that the growth of banking sector and the stock market were extremely correlated with the economic growth and both sectors exerted an important impact on growth of a country. [7] Ang (2008), further found that the financial sector played a very important role in mobilizing and better consumption of saving in economic development. Considerable more literature existed on the debate of financial sector development support toward economic development. Traditionally, [8] Bagehot (1873) and [9] Schumpeter (1912), highlighted the role of financial sector in economic development. [10] Levine and Zervos (1998) and King and Levine (1993), examined the involvement of financial sector on output growth in cross-countries analysis. [11][12] Arestis (2001), Shan 
(2002) and Abu-Badar (2005), explored the link between financial sector development and economic growth. It shows bank based model contributed more to output growth in long run than the stock market based model.

On showing the correlation between economic and sustainable development, [13] Dalal-Cloyton and Bass (2002), explain what they actually mean, according to them, meeting the need of the present generation cover the economic need, social, cultural and health plus the political need. On the other hand without dislocate the future compeers ability to meet their own needs, refers to minimizing usage, the sustainable use of renewable resources and keeping with the absorption capacity of local and global sink for wastes.[14] Johannesburg Declaration (2002), found that the commitment to sustainable development is reference one more and the challenges in-directed. Another research document written by [15] Kyo-to-Protocol (1997), which was take on with a direct focus on global warming related to sustainable and economic development. [16] Wood (2002), maintains that sustainable development deliberates a contested paradigm, since the term 'sustainability " is imprecise in itself and more significantly, it takes an approach that tackles the irreconcilability among economic, social and environmental measurements. In which we are able to solve such kind of problem with the help of a paradigmatic shift which is necessary according to time.

To established the relationship between finance and sustainable development. According to [17] Bazin et al. (2004), says that the companies take their accountability via-a-vise the sustainable development into the account by declining their negative environmental impacts through the execution of environmental policies, strategies and operation. [18] Faucheux et al. (2003), found that the companies also grasp for the social field, related to the company esteem toward the social dimension of the way in which they demeanor their business. [19] Gompers et al. (2003), indicated that an progress in corporate governance has greater impact on the financial performance of a company that the entire level of corporate governance performance.[20] Cerin (2004), concluded that the companies go for sustainable development only on the basis of image building of the company. To show the positive correlation between sustainable development and financial activity, various study are conducted by [21] Das-Gupta et al. (2002), [22] Hart (1995), [23] King et al. (2000), [24] Klassen et al. (1996), [25] Schaltegger et al. (2000) and [26][27] Steger $(2000,2004)$

\section{Objectives}

- Try to give basic idea related to the concept of Sustainable Development;

- Study the relationship between Finance, Economics and Sustainable Development; and

- Developed Functional \& Mathematical Relationship between Finance, Economics and Sustainable Development along with the method of error calculation;

\section{Research Methodology}

Research methodologies used in this paper are the combination of Qualitative, Fundamental and Conceptual type of research. In 'Qualitative Research', we have study various research papers, articles, annual reports, books and also conduct personal interview so as to get a deep understanding of relationship between finance, economics and sustainable development. The 'Fundamental Research' is mainly concerned with the generations and with the formulation of theory, "Gathering knowledge from knowledge's sake in termed 'pure' or 'basic' research". This type of research concerning some natural phenomenon or related to pure mathematics, with the help of this type of research technique we have developed econometrics relationship between above three variable. Finally the 'Conceptual Research' is that related to some abstract ideas or theory. It is generally used by philosophers and thinkers to developed new concepts or to interpret existing one, with the help of this type of research technique we have developed new type of graphical and mathematical relationship between finance, economics and sustainable development, which shows how these three variables are interrelated to each other.

\section{Identification of Relationship Functions between Finance, Economics And Sustainable Development} Relationship between Finance and Economics:

Finance is dealing the inflow of money such as cash, investment, stocks, funds etc. It also refers to the concept of time and risk inter related. Economics is about the supply and demand also managing the production, consumptions, distributions of goods and services. The Finance \& Economics are related to each other as the economics is managing the cash flow to a financing complex, such as investment, funds, goods \& services. Directly and indirectly finance and economy are the part of one coin both of them are always correlated with each other. For example: Before making any economic policy, government first make budget of that policy then try to implement that policy into action. To understand this relationship we will take live example of Indian government scheme [28] MGNREGA (Mahatma Gandhi National Rural Employment Guarantee Act, 2005) which help rural people to give 100 days' employment with a rate of Rs. 120 per day, per village people. With the help such kind of financial scheme rural people are not interested to move toward urban area and this scheme also helps village people to work on his/her agriculture land in the remaining days. On the basis of overall setup of this scheme we conduct some qualitative research. In which we take personal interview of the 
rural people in related to that scheme and ask various type of question which indicate the relationship between financial support and economic development. SPSS output are shown in table 1.1 which shows correlation between these two activities on the basis of five questions which are given blow:

Size of Sample: 200Respondents;

Area: Dadri, Kalva, Dankoor and Mehraval, these villages are located in UP.

Cronbach's Alpha $(\propto)=0.697$

Where:

Q1: Are you satisfied with the scheme of 100 days employment;

Q2: This Scheme improves your quality of life in village;

Q3: This scheme helps you in agriculture financial support;

Q4: With the help of this scheme, are you also able to serve your family; and

Q5: Are you got enough time to cultivate your land after spending 100 days with that scheme;

Table 1.1

Correlation Between above questions

\begin{tabular}{|c|c|c|c|c|c|}
\hline & Q1 & Q2 & Q3 & Q4 & Q5 \\
\hline $\begin{array}{c}\text { Q1 Pearson correlation } \\
\text { Sig. (2-tailed) } \\
\text { N }\end{array}$ & 1 & & & & \\
\hline $\begin{array}{l}\text { Q2 Pearson correlation } \\
\text { Sig. (2-tailed) } \\
\text { N }\end{array}$ & $\begin{array}{r}.654 * * \\
.002 \\
200\end{array}$ & 200 & & & \\
\hline $\begin{array}{l}\text { Q3 Pearson correlation } \\
\text { Sig. (2-tailed) } \\
\text { N }\end{array}$ & $\begin{array}{r}.619 * * \\
.004 \\
200\end{array}$ & $\begin{array}{r}.342 * \\
.005 \\
200\end{array}$ & 200 & & \\
\hline $\begin{array}{l}\text { Q4Pearson correlation } \\
\text { Sig. (2-tailed) } \\
\text { N }\end{array}$ & $\begin{array}{r}.354^{*} \\
.005 \\
200\end{array}$ & $\begin{array}{r}.767 * * \\
.000 \\
200\end{array}$ & $\begin{array}{r}.498^{* * *} \\
.004 \\
200\end{array}$ & 200 & \\
\hline $\begin{array}{l}\text { Q5 Pearson correlation } \\
\text { Sig. (2-tailed) } \\
\text { N }\end{array}$ & $\begin{array}{r}.562 * * \\
.003 \\
200\end{array}$ & $\begin{array}{r}.645^{* *} \\
.002 \\
200\end{array}$ & $\begin{array}{r}.368 * \\
.005 \\
200\end{array}$ & $\begin{array}{r}.321 * \\
.005 \\
200\end{array}$ & 200 \\
\hline
\end{tabular}

**Correlation Significance at the 0.01 level (2-tailed)

On the basis of above correlation table you will easily understand that financial activity are positively correlated with economic development. If we convert this above relation in mathematical function then we write this is in the form of equation which is given blow:

$$
E_{d}=f\left(F_{a}\right)
$$

It means Economic Development $\left(E_{d}\right)$ are depend upon Financial Activity $\left(F_{a}\right)$

\section{Relationship between Finance and Sustainable Development:}

Main objective of Sustainable developments is to save natural resources for future, which would be used by our future generation. For such kind of development, government or organization should do 'Fiscal Management' with the help of that management they have to know, how to generate revenue for further expenditure related to research and development program. For example: replacement of petroleum device by solar system device, create nuclear power plant instead of water operated electric plant and other similar kind of activity. Government or an organization required huge amount of capital to develop such kind of project which give sustainable development and secure present natural resources for future. There are so many examples available in India, which shows that without financial support sustainable development are not take place. In this regard on the basis of our literature review we also concluded that corporate housed are also invent some portion of his income in sustainable development to improved environmental condition. If you study the annual report of best thirty companies in India, who are listed in SENSEX (Mumbai Stock Exchange). Then you are easily understood that, every company is interested to invest some amount of his income before or after tax in sustainable development. Industry wise sustainable investments are given blow in figure 1.1; 
Figure 1.1

Sector wise investment in sustainable development in India

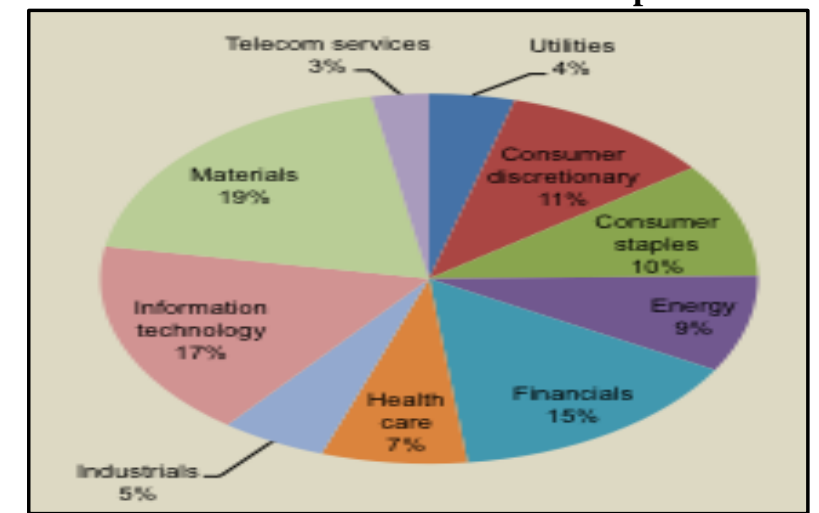

Source: Sustainable investment activity Report by IFC in 2009

On the basis of above discussion, we will convert the above relationship in to a mathematical function in to the form of equation which are given blow:

$$
S_{d}=f\left(F_{a}\right)
$$

It means Sustainable Development $\left(S_{d}\right)$ is depend upon Financial Activity $\left(F_{a}\right)$

\section{Relationship between Economics and Sustainable Development:}

Economics and sustainable development are strongly related to each other, when economic development take place then sustainable development also takes place. For example, if India government establish EPZ/SEZ to promote industrialization in particular area by given him special tax provision related to SEZ, so employment generation take place in that area, on that effect living standard of people also improve, then their children also get good education and they know how to secure natural resources for future. On the basis of above discussion, we will convert the above relationship in to a mathematical function in to the form of equation which are given blow.

$$
S_{d}=f\left(E_{d}\right)
$$

It means Sustainable Development $\left(S_{d}\right)$ is depending upon Economic Development $\left(E_{d}\right)$.

\section{Functional \& Mathematical Relationship Between Finance, Economics And Sustainable}

Where: Development

$F_{a}=$ Financial activity; and

From equation (1)

$$
E_{d}=\text { Economic development; }
$$

$$
E_{d}=f\left(F_{a}\right) \pm \text { Error }_{1}
$$

It means $F_{a}$ is the function of $E_{p}$, When Financial activity increase then Economics activity also increase but not in same proportion due to Error in policy formulation and implementation.

From equation (3)

$$
\begin{aligned}
\Rightarrow \quad S_{d} & =f\left(E_{d}\right) \pm \text { Error }_{2} \\
\Rightarrow & S_{d}=f\left(f\left(F_{a}\right) \pm \text { Error }_{1}\right) \pm \text { Error }_{2}
\end{aligned}
$$

Where: Error $_{1}$ and Error ${ }_{2}$, are the problems which are created due to external environments.

Suppose Error $_{1}=0$ and Error $_{2}=0$

$$
\Rightarrow \quad S_{d}=f\left(f\left(F_{a}\right)\right)
$$

Then equation (6) becomes perfect after eliminating Error in the above equation.

If we are interested to calculate Error

Let: The Equation of financial Activity is given by:

$$
F_{a}: b y=\mathrm{ax}+\mathrm{c}
$$

The Equation of Economic Development is given by:

$$
E_{d}:(x-\alpha)^{2}=4 a(x-\beta)
$$

If, we considered standard equation of Financial activity $\left(F_{a}\right)$, and convert it is in the form of intercept, then equation (8) become

$$
\Rightarrow \quad y=\frac{a}{b} x+\frac{c}{b}
$$

Let: Assume that $\mathrm{Y}$ intercept is Zero $\left(\frac{c}{b}=0\right)$, then equation (10) become 


$$
y=\frac{a}{b} x
$$

If, we considered Standard equation of Economic Development $\left(E_{d}\right)$, then equation (9) become

$$
\Rightarrow \quad x^{2}+\alpha^{2}-2 x \alpha=4 a y-4 a \beta
$$

Let: Assume that $(\alpha=0, \beta=0)$, then equation become

$$
x^{2}=4 a y
$$

According to equation (11) and (13) draw curve which include Error 1 and Error 2 as a intersection part of both curve and line,

$$
\left(y-\frac{a}{b} X=0\right) \cap\left(x^{2}-4 a y\right)
$$

Figure 1.2

Graphical relationship between Financial Activity and Economics Development

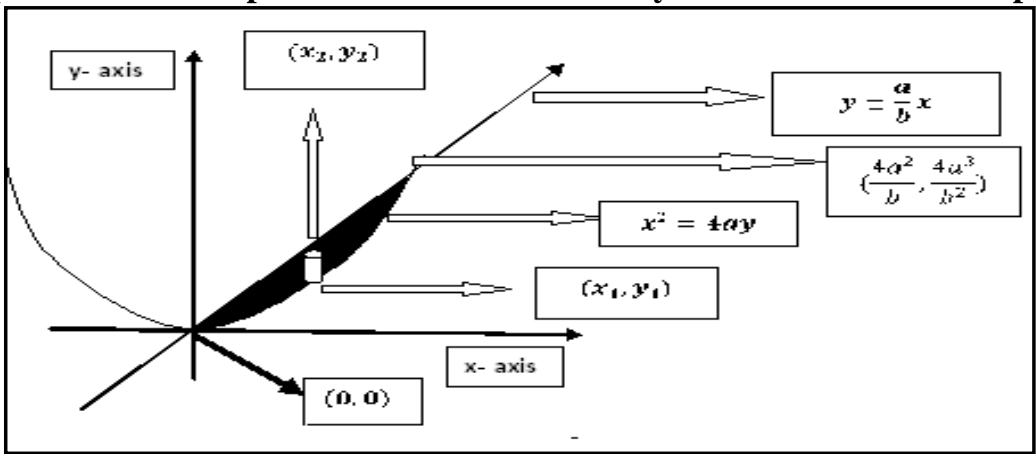

That black region in the above figure is called Error factor. To calculate that region you go for definite integration.

$$
\begin{aligned}
& \text { Total Error }\left(\text { Error }_{1}+\text { Error }_{2}\right)=\int_{0}^{\frac{4 a^{2}}{b}}\left(y_{2}-y_{1}\right) d x \\
& \text { Total Error }=\int_{0}^{\frac{4 a^{2}}{b}}\left(\frac{a}{b} x-\frac{x^{2}}{4 a}\right) d x
\end{aligned}
$$

Equation (16) calculates total error between financial activity and economic development. Due to this realistic error in economic development, which creates inconsistency in sustainable development; In other words, it creates low level growth in sustainable development with respect to finance and economic development. Above figure 1.2 represent ideal conditions in which financial activity are perfect but in real world this relationship is not like that, it shows different type of distinctive curves which represent the actual position between finance and economic development.

\section{Conclusion}

While reading this paper researcher and student, easily understand the mathematical and functional relationship between finance, economics and sustainable development. With the help of equation $(7)\left[S_{d}=f\left(f\left(F_{a}\right)\right)\right]$, we easily concluded that sustainable development is a function of economic development which in turn is dependent on financial activity of an economy. This paper also designs the method to calculate the possible error between financial activity, economic development and sustainable development.

\section{References}

[1] United Nations, Report of the World Commission on Environment and Development, General Assembly Resolution 42/187, 11 December 1987. Retrieved: 2007-04-12

[2] Smith, Charles; Rees and Gareth, Economic Development, 2nd edition. Basingstoke: Macmillan, 1998.

[3] Stivers R., The Sustainable Society: Ethics and Economic Growth, Philadelphia: Westminster Press, 1976.

[4] Daly H. E., Towards a Steady State Economy. San Francisco: Freeman (1 ${ }^{\text {st }}$ ed.), 1973, Daly H. E., Steady-State Economics (2nd ed.), 1991, Washington, D.C.: Island Press.

[5] Levine R., Financial Development and Economic Growth: View and Agenda, Journal of Economic Literature, 35(3), 1997, 688726.

[6] Beck T., Demigruc-kunt A. and Levine R., A New Database on Financial Development and structure, World Bank Economic Review, 14, 2000, 597-605.

[7] Ang J.B, Finance and Inequality: The case of India, Monash University Department of Economics Discussion Paper, August, 2008, 26-39.

[8] Bagehot, A Description of Money Market with Currency Monopoly, Homewood ILRichard, 1962.

[9] Schumpeter J., The Theory of Economics Development, Harvard University Press, 1912. 
[10] Levin R. and Zervos S., Stock Market, Bank and Economic growth, The American Economic Review,88(3), 537-588.

[11] Arestis P., Panicos O.D. and Kul B., Financial Development and Economic Growth: The Role of Stock Market, Journal of Money Credit and Banking,33(1), 2001, 16-41.

[12] Abu-Badar S. and Abu Qarn A. S., Financial Development and Economic Growth: The Egyptian Experience, Discussion paper: Monaster Cebter for Economic Research, Ben Gurion University of Negev PO Box 653, Beer Sheva Israil, 2005, 1-36.

[13] Dalal-Clayton B. and Bass S., Sustainable Development Strategies: A Resource Book, London Earth-scan Ltd, 2002.

[14] Kyo-to-Protocol, United Nation frame work convention on climate change, June 2012, Retrieved from file http//tmp/M221252000E.pdf.

[15] Johannesburg, Declaration on Sustainable Development in United Nation, Retrieved from http:www.undocuments.net/jburgdec.html, May 20, 2010

[16] Woods D., Sustainable Development: A Contested Paradigm, Economic forum of Foundation for water research, Birmingham, U.K, 2002 .

[17] Bazin D. and Ballet J., Corporate Social Responsibility: The Natural Environment as a Stakeholder, International Journal Of Sustainable Development, 7(1), 2004, 59-75.

[18] Faucheux S. and Nicoloi I., From Sustainable Development to corporate social responsibility: An Application to the European aluminum, International Journal of Sustainable Development, 6(2), 2003, 155-169.

[19] Gompers P., Ishii J. and Metrick A., Corporate governance and Equity Price, The Quarterly Journal of Economics, February 2003, $107-155$

[20] Cerin P., Where is Corporate Social Responsibility actually heading?, Progress In Industrial Ecology, 1(1/2/3), 2004, 307-330.

[21] Dasgupta S., Laplante B., Wang H. and Wheeler D. Confronting the Environmental Kuznets Curve. Journal of Economic Perspectives 16(1), 2002, 147-168.

[22] Hart S., A natural resource-based view on the firm, Academy of Management Review, 20, 1995, 986-1014

[23] King A.A. and Lenox M.J., Industry self-regulation without sanctions: The chemical industry's responsible care program, Academy of Management Journal, 43(4), 2000, 698-716

[24] Klassen R.D. and McLaughlin C.P., The impact of environmental management on firm Performance, Journal of Management Science,42(8), 1996, 1199-1214.

[25] Schaltegger S. and Figge F., Environmental Shareholder Value: Economic Success with Corporate Environmental Management, Journal of Eco-Management and Auditing, 7(1), 2000, 29-42.

[26] Steger U., Environmental management systems: Empirical evidence and further perspectives. Journal of European Management Journal, 18(1), 2000, 23-37.

[27] Steger U., What is the Business Case for Corporate Sustainability, Perspectives for Managers, June 2004: 2-4.

[28] http://www.tnrd.gov.in/schemes/nrega.html 